\title{
The Global Competitiveness Of The Nation: A Conceptual Discussion
}

Alain Nurbel, (E-mail: nurbel@univ-reunion.fr), University of La Reunion, CERESUR, France

\begin{abstract}
The recurrent use of the concept of international competitiveness in order to explain differences in performances between firms and between countries induces to wonder about the content at which it refers. The plurality of the involved economic levels is certainly not irrelevant to the vagueness in which the concept is rooted. The subject of this article consists in contributing to break up the vagueness surrounding the concept by showing its richness within the framework of a presentation of the foundations of the nation's global competitiveness in terms of factors and results.
\end{abstract}

\section{INTRODUCTION}

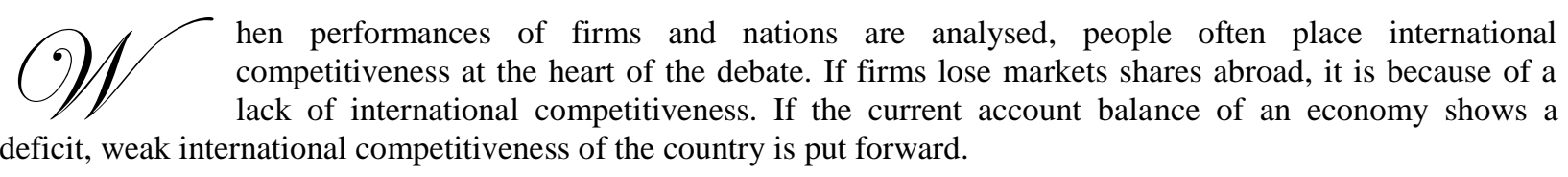

However, although international competitiveness is often referred to in discussion on firms' and nations' performances, we are to state that this concept is not clearly defined. In reality, the diversity of the definitions which are given according to the ends which one intends to reach results in the suspicion that not enough attention has been paid to what the concept of international competitiveness really means.

According to us, it is interesting to emphasise how much the concept of international competitiveness is rich, by relying on the framework of "the global competitiveness of the nation". The point of departure of our proposition is our thorough conviction that international competitiveness can been seen both as a "result" and a "determining factor". It is that way we choose to follow in order to clear up the vagueness in which the concept of international competitiveness is rooted. Our approach is intentionally synthetic.

If we choose to speak about "the global competitiveness of the nation" rather than the "international competitiveness of the nation", it is because it succeeds in better accounting for the fact that the microeconomic, mesoeconomic and macroeconomic levels are simultaneously involved in the performance of a nation. However, the question whether it is rational to apply the concept of competitiveness to the nation is still a relevant one. Following the explanation of the birth of the question of competitiveness for nations, we make the distinction between two great determining factors, namely the non price competitiveness of firms and the structural competitiveness of the nation. The last section concludes. 


\section{SPEAKING ABOUT COMPETITIVENESS FOR NATIONS: WHY CAUTION IS NEEDED}

If one considers that the competitiveness of a firm may be defined as its capacity to sell, then it can be assumed that the competitiveness of a nation, by analogy, corresponds to its ability to sell more to the rest of the world than it buys from it. Then, the information on the global competitiveness of a nation is thought to be given by the situation of its current balance: bigger is the current account surplus, better is the international competitiveness of the nation.

However, considering the current account balance as an indicator of competitiveness of the nation raises a problem, in so far as the transitivity property is not always respected (Dluhosch, Freytag, Krueger [1996], pp.65-66). Indeed, if a country A has a bilateral current surplus with a country B and country B gets a bilateral current account surplus with country $\mathrm{C}$, country A may have a current account deficit with country $\mathrm{C}$. This situation is not a contradictary since the international trade is, for a part, driven by the law of comparative advantages. What a nation imports or exports results from its comparative advantages.

The neoclassical theory of international trade is well suited to the explanation of the inter-industry specialisation, namely the specialisation by which the structure of the external trade of the nation is distinguished by the presence of products which are either "highly exported" or "highly imported". By omitting the case where flows of imports and flows of exports for a same product are equivalent, the law of factors proportions loses its utility in the face of the intensity of intra-industry exchanges between industrialised nations. The question of the global competitiveness of a nation is relevant only with regard to crossed exchanges of similar products.

Another problem arises from the fact that the fundamental goal of a nation is not the growth of its current account, but the growth of the real income of its citizens for which the improvement of the domestic productivity is the crucial motor. In other words, we should have in mind that nations do not compete with each other like firms compete with each other. The analogy between nations' competitiveness and firms' competitiveness is false (Krugman [1994a], [1994b]; Krugman [1996]).

\section{THE PARADOX OF COMPETITIVENESS}

\section{Divergence Between Ex Ante Competitiveness And Ex Post Competitiveness}

It can be considered that the question of competitiveness for a nation arises when there is a divergence between "ex ante competitiveness" and "ex post competitiveness". Ex ante competitiveness lies on indicators of real exchange rate which can be calculated by using export prices, import prices and unit labour costs. Ex post competitiveness is given by the situation of the current account balance.

The divergence is the paradox that the way the current account balance changes following a variation in $e x$ ante competitiveness is not consistent with what was expected. For example, Japan's structural current account during the eighties in spite of yen's real appreciation can be considered as a stylised fact of "virtuous" divergence between ex ante competitiveness and ex post competitiveness. On the contrary, when current balance deteriorates while domestic currency depreciates is a fact of "vicious" divergence.

\section{Where Does It Come From?}

Pricing to market behaviours of firms play certainly a role, in that exchange rates variations are only partially passed through external prices (Gagnon and Knetter [1992]; Knetter [1993]; Athukorala and Menon [1994]). However, they are far from being the only one cause of competitiveness paradox.

For us, the paradox of competitiveness is profoundly rooted in the concept of non price competitiveness. Through this concept, one is driven to narrow the place which is usually given to the "traditional" factors of competitiveness, namely costs and prices. Indeed, "non costs advantages recover the characteristics peculiar to the product (quality, reliability, innovation, adaptation to needs), to networks of marketing and to the stability between 
producers and their partners" (Mathis, Mazier and Rivaud-Danset [1988], p.8). The non price competitiveness does not mean that costs and prices are swept away. Non price or non costs competitiveness "does not result from the decrease of the cost or the price of the product, but from the characteristics which incite the users to prefer it to its competitors. These characteristics, whatever their nature are, differentiate the product and explain the fact that its producers are in a monopoly situation or, more exactly, in a situation of monopolistic competition. Indeed, it is clear that the monopoly position is not perfect in so far as, whatever the qualities of the product are, it is still in competition with substitutes" (Mathis, Mazier and Rivaud-Danset [1988], p.169). So, non price competitiveness should be considered as a determining factor of the global competitiveness of the nation.

The paradox of competitiveness can also be explained by the structural competitiveness. Indeed, the notion of structural competitiveness is adopted "as a way of expressing the fact that, while the competitiveness of firms obviously reflects successful management practices, it also stems from the strength and efficiency of a national economy's productive structure, its technical infrastructure, and other factors determining the "externalities" on which firms can build" (Chesnais [1991], p.142).

If one comes back to the definition of the non price competitiveness, one can note that it contains an element of structural competitiveness, namely the stability of the relations between producers and their partners. So, it is relevant to consider the concept of non price competitiveness in a wide way. By doing so, we are able to consider that going beyond the traditional factors of competitiveness results in taking into account factors located on three levels:

i) the microeconomic level, which gathers elements like the quality of products.

ii) the mesoeconomic level, characterised by the stability of the relations between producers and firms which are upstream and downstream the production process. Firms are never alone in the international competition. The strength of the relations with suppliers and distributors becomes a factor of competitiveness.

iii) The macroeconomic level represented by innovation. If it is true that the performances of an economy first depend on firms, one should acknowledge that the attributes of the nation are likely to influence firms' performances by the channel of innovation. In other words, importance must be given to the national system of innovation. The emergence of this concept during the eighties spread the theory that "innovation is (...) structurally determined both by economic and political factors which are outside the firm. So the national innovation systems appear in the theoretical field in an effort of explanation of the development of the innovative activity" (Niosi, Bellon, Saviotti and Crow [1992], p.216).

The academic definition of the concept of non price competitiveness appears limited as it provides no information on the relative importance on its components. In order to remove this shortage, it is necessary to adopt a new framework, namely a presentation in terms of factor and result. We are then induced to distinguish between two great determining factors of the global competitiveness of the nation, namely the non price competitiveness of firms and the structural competitiveness of the nation.

\section{THE NON PRICE COMPETITIVENESS OF FIRMS}

Since firms are the fundamental actors of competition, one should consider the non price competitiveness of firms as the microeconomic aspect of the global competitiveness of the nation: it is its first great determining factor. It comprises a result side, represented by the differentiation competitiveness of the product, which recovers the competitiveness of the price-quality ratio, and a factor side which corresponds to the competitiveness of the internal organisation of the firm. 


\section{The Price-Quality Competitiveness}

What does price-quality relation mean? We propose a "synthetic theory of the purchase decision" which lies at the centre of a typology of the price-quality relation. This theory comprises three parameters:

i) the price.

ii) the quality, which include both horizontal and vertical aspects which are peculiar to products.

iii) the implicit costs of consumption, which concerns the cost related to the after sales service.

By taking into account the price-quality competitiveness, we can understand why there is paradox of competitiveness. The deterioration of the price competitiveness owing to an appreciation of the currency may not change the perception of the price-quality competitiveness. It is the case when consumers do not think that the quality of the product is supplied at a too much expensive price, although this one has increased.

When we consider that a better differentiation competitiveness of products corresponds to a better competitiveness of the price-quality ratio, we are located in the "objective" area of the differentiation. However, two factors belonging to the strategic area of the differentiation are likely to disturb the real place of products in a quality-price space:

i) the free-rider behaviour adopted by firms which offer the inferior quality. In a context where prices are considered as good signals of quality and where the nature of the differentiated products are such that objective levels of qualities can be revealed only after a sequence of costly recurred purchases, consumers can be victim of illusion as they may buy the inferior quality sold at a price similar to that of the superior quality. The firm which produces and offers the best quality is victim of the free-rider behaviour of that which produces and offers the inferior quality: markets shares for its products are below those expected. A strong commitment strategy, for example a costly non informative advertising, is needed to overcome the free-rider strategy.

ii) strategies of prices, namely limit-price and predator-price strategies (Rey and Tirole [1997]), may be adopted by firms that possess strong financial reserves. These reserves allow the firm to improve the competitiveness of the price-quality ratio, but only by the channel of prices.

\section{The Internal Organisational Competitiveness Of A Firm: The Role Of Informal Transactions}

Creating competitive products, defined as products which exhibit a good price-quality ratio, also results from the competitiveness of the internal organisation of the firm. The propensity of a firm to convert the advantages that it possesses, for example on the level of technology, into competitive products basically depends on the degree to which employees agree to share its aims. Then controlling as better as it can do the opportunistic behaviours appears like a significant intermediary goal on the road towards differentiation competitiveness. The organisational competitiveness of the firm is based on a structure of internal incentives which is likely to give value to "informal transactions" (Charreaux [1990]) between employees. These informal transactions concern the propensity of individuals to make easier the transmission of information and orders through the hierarchical structure.

In order to illustrate these propositions on the role of informal transactions as a factor which shapes the differentiation competitiveness of the firm, one can pay a particular attention to the structure of internal incentives of the Japanese firm which lies on the rank hierarchy. While occidental firms adopt a mode of compensation which is based on the task which must be accomplished, the Japanese firm evaluate the employee on the ground of its "faculty to live in the context of the firm" (Aoki [1991], p.54). This characteristic results from the particularity of the classification and the attribution of tasks which are large and flexible in the firm J. In such a system, cooperation and competition within the firm. 


\section{THE STRUCTURAL COMPETITIVENESS OF THE NATION}

The second great determining factor of the global competitiveness of the nation is represented its structural competitiveness. It is formed by two components, namely the competitiveness of the structures of firms and the competitiveness of the national structure.

\section{The Competitiveness Of The Structures Of Firms}

Firms are not alone in the international competition. They have relations with others firms upstream and downstream their productions. As competing internationally demands productivity and flexibility, the strength of the ties between firms is a first factor of competitiveness outside of the microeconomic area. We we can pay attention to keiretsu organisations (Miyashita and Russel [1996]).

The relative superiority of japanese firms' performances during the eighties are based, in a certain proportion, on their success on their membership to networks of partially integrated firms. Inter-firms relations inside such organisations are characterised by long term relations and reputation.

\section{The Competitiveness Of The National Structure}

Firms which compete on international level are a part of their own national environment. So, one can states that, in some extent, their strategies are impregnated by the characteristics of the nation to which they belong. In this, the competitiveness of the national structure represents the second component of the structural competitiveness of a nation. This national structure constitutes the ground where interactions generate the forces which may influence the non price competitiveness of firms.

The first part of interactions is peculiar to the national innovation system. The original bases of its definition (Lundvall [1985], Freeman [1987], Nelson and Rosenberg [1993]) and the lessons which can be drawn from the japanese economy during the eighties lead to an academic definition at the centre of which lies the role that the State can play in the innovative process. In this, the national innovation system of Japan can explain a part of its relative superiority in the technological field. Japan's national system of innovation possesses four characteristics, namely "a strong impetus from the central government in order to promote the modernisation of the japanese economy, the identification of education and training as key factors in this modernisation, intense efforts to import and whenever possible to improve upon the best available technology in the world, and the close co-operation between government and large industrial concerns" (Freeman [1987], p.32).

The second part of interactions is wider than the first one and concerns the four attributes which form the "national diamond" (Porter [1990]), namely factors conditions, demand conditions, firm strategy, structure and rivalry and related and supporting industries. These attributes are at the basis of the interdependence ties which may appear between national economic entities. The quality of these interactions is a determinant of the differentiation competitiveness of the firms.

Finally, the presentation of the foundations of the global competitiveness of a nation in terms of factor and result may be summarised by the precedent diagram (Diagram 1, p.12).

\section{CONCLUDING REMARKS}

The aim of this paper has been to try to break up the vagueness which surrounds the concept of international competitiveness by using a presentation in terms of factors and results, within a framework of the foundations of the global competitiveness of a nation.

The problematic of the international competitiveness settles strongly when the situation of the current account balance, which is considered as an indicator of the ex post competitiveness, is not consistent with the signals which are sent by the evolution of real exchange rates, which are indicators of ex ante competitiveness. 
The explanation of the divergence between ex ante competitiveness and ex post competitiveness is based on two great determining factor, namely the non price competitiveness of firms and the structural competitiveness of the nation. The non price competitiveness of firms comprises a "result dimension", represented by the competitiveness of the price-quality ratio, and a "factor dimension" which recovers the internal organisational competitiveness of the firm. However, firms are not isolated actors facing international competition. They have upstream and downstream relations with other firms. The soundness of these ties within networks or structures of firms constitutes the first component peculiar to the structural competitiveness of the nation. At the same time, firms interact with their national environment which provide the externalities which influence their strategies, and basically their capacity to innovate. At the centre of these externalities, one may attribute a significant place to an effective State. In this, the competitiveness of the national structure constitutes the second component of the structural competitiveness of a nation.

We wish to add few words on what should be competitiveness policy of government in the context of globalisation. It is acknowledged that foreign direct investments of multinational firms play a significant role in the economic and industrial development of host nations (Markusen and Venables [1999]; UNCTAD [1999]; Borensztein, De Gregorio and Lee [1998]; Olofsdotter [1998], Rodriguez-Clare [1996], Ozawa [1992]). Above all, it appears that natural assets do not stand any more the exclusive determining factor of the international production (Dunning [1999]). Since multinational firms are increasingly sensitive to their transaction costs, created locationbound assets which a nation can offer become a significant determining factor of their localisation. Accordingly, multinational firms' behaviours are likely to improve the structural competitiveness of a host nation and so the non price competitiveness of indigenous firms (Dunning [1997a]; [1997b]; [1997c]). A good policy of competitiveness should be based on measures which are dedicated to the improvement of the national structure, among which openness to foreign direct investments and multinational firms (Dunning [1992a], [1992b]). 
The foundations of the global competitiveness of the nation

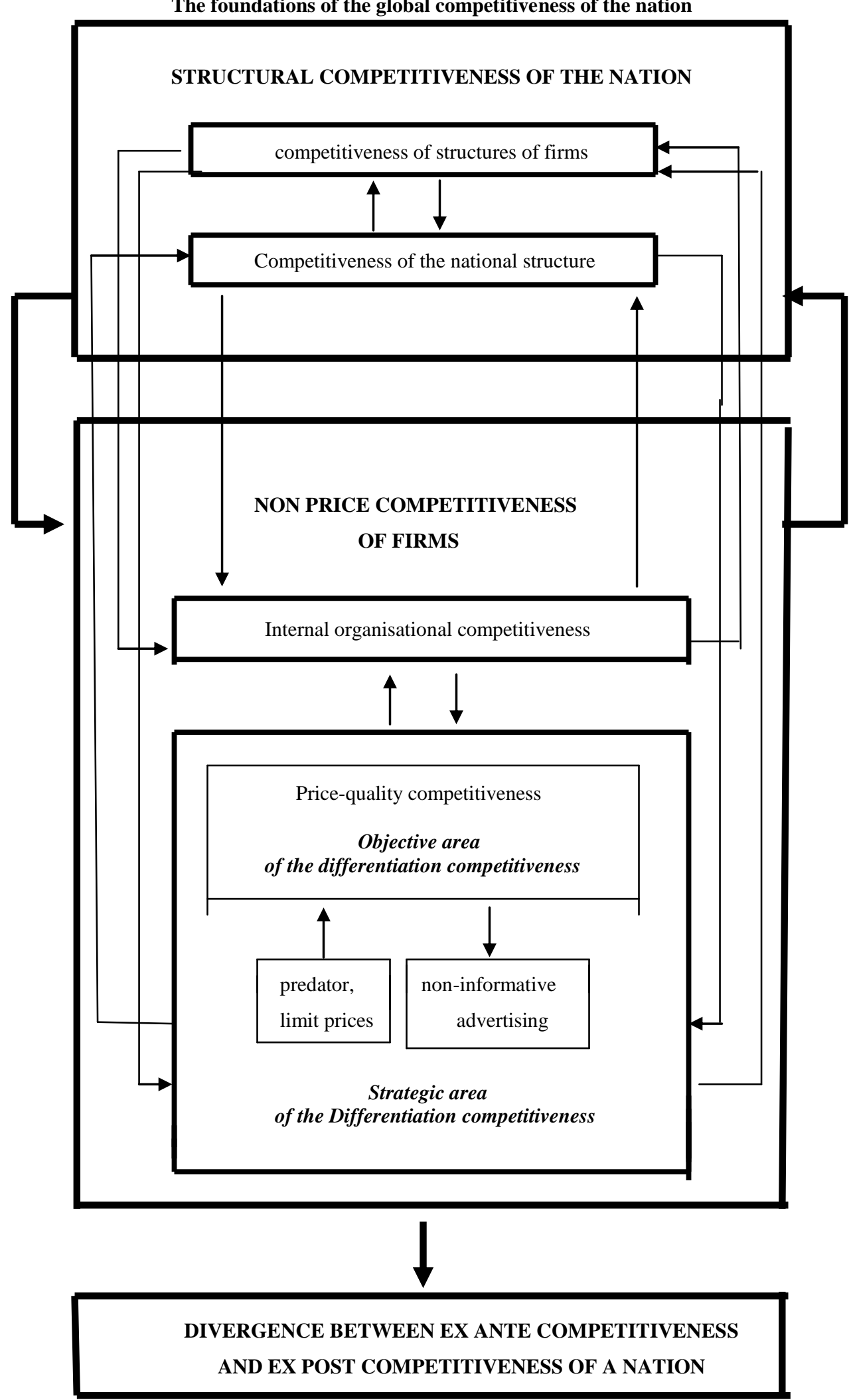




\section{REFERENCES}

1. Amendola G., Dosi G., Papagni E., [1993], The Dynamics of International Competitiveness, Weltwirtschafliches Archiv, vol.129, n³, pp.451-471.

2. Aoki M. [1991], Economie japonaise. Information, motivations et marchandage, Economica, 354p.

3. Aoki M., Dore R. [1994], The Japanese Firm. Sources of Competitive Strength, Clarendon Press Oxford, 410p.

4. $\quad$ Athukorala P., Menon J. [1994], Pricing-to-Market Behaviour and Exchange Rate Pass-Through in Japanese Exports, Economic Journal, vol.104, n423, mars, pp.271-281.

5. Beath J., Katsoulacos Y. [1991], The Economic Theory of Product Differentiation, Cambridge University Press, 204p.

6. Bellon B., Niosi J. [1994], Des systèmes nationaux d'innovation ouverts, Revue française d'économie, vol.IX, hiver, pp.79-130.

7. Borensztein, E., J. De Gregorio, J-W. Lee [1998], How does foreign direct investment affect economic growth?, Journal of International Economics, 45, pp.115-135.

8. Charreaux G. [1990], La théorie des transactions informelles: une synthèse, Economies et Sociétés, mai, pp.137-161.

9. Chesnais F. [1991], Technological Competitiveness as a Form of Structural Competitiveness in NIOSI J. Technology and National Competitiveness, McGill-Queen's University Press.

10. Coriat B., Weinstein O. [1995], Les nouvelles théories de l'entreprise, Inédit, 218p.

11. Dalagamas B. [1995], Export Performance and Its Determinants: A Study for Japan Vis-à-Vis Its Major Trading Partners, Hitotsubashi Journal of Economics, n³6, pp.71-91.

12. Dluhosch B., Freytag A., Krueger M. [1996], International Competitiveness and the Balance of Payments. Do Current Account Deficits and Surpluses Matter?, Edward Elgar, 231p.

13. Dosi G., Freeman C., Nelson R., Silverberg G., Soete L. [1988], Technical Change and Economic Theory, Pinter Publishers, 646p.

14. Dosi G., Pavitt K., Soete L. [1990], The Economics of Technical Change and International Trade, Harvester Wheatsheaf, 303p.

15. Dunning, J.H. [1992a], Governments, markets, and multinational enterprises: some emerging issues, International Trade Journal, vol.7, $\mathrm{n}^{\circ} 1$, pp.1-14.

16. Dunning, J.H. [1992b], The global economy, domestic governance, strategies and transnational corporations: interactions and policy implications, Transnational Corporations, vol.1, n³ 3 , décembre, pp.745.

17. Dunning, J.H. [1993], Governments and multilateral activity: the unilateral response in Dunning, J.H., Multinational enterprises and the global economy, Addison-Wesley Publishing Company, pp.547-573.

18. Dunning, J.H. [1997a], Re-evaluating the benefits of foreign direct investment in Dunning, J.H., Alliance capitalism and global business, Routledge, pp.209-233.

19. Dunning, J.H. [1997b], Some paradoxes of the emerging global economy. The multinational solution in Dunning, J.H., Alliance capitalism and global business, Routledge, pp.357-373.

20. Dunning, J.H. [1997c], The concept of country competitiveness, in Dunning, J.H., Alliance capitalism and global business, Routledge, pp.271-279.

21. Dunning, J.H. [1999], Regions, globalization and the knowledge economy: the issues stated, Colloque Les stratégies des entreprises multinationales, Université de Paris 1 Panthéon-Sorbonne, 17 et 18 juin 1999, $62 \mathrm{p}$.

22. Fagerberg J. [1988], International Competitiveness, Economic Journal, vol.98, n³91, pp.355-374.

23. Flath D. [1996], The Keiretsu Puzzle, Journal of the Japanese and International Economies, $\mathrm{n}^{\circ} 10$, pp.101121.

24. Freeman C. [1987], Technology Policy and Economic Performance. Lessons from Japan, Pinter Publishers London, $149 \mathrm{p}$.

25. Gagnon J.E., Knetter M.M. [1992], Mark-up Adjustment and Exchange Rate Fluctuations: Evidence from Panel Data on Automobile Exports, NBER Working Papers Series, $\mathrm{n}^{\circ} 4123$, juillet, 31p.

26. Hickman B.G. [1992], International Productivity and Competitiveness, Oxford University Press, 407p. 
27. Hughes K. [1992], Technology and International Competitiveness, International Review of Applied Economies, vol.6, $\mathrm{n}^{\circ} 2$.

28. Jacquemin A. [1985], Sélection et pouvoir dans la nouvelle économie industrielle, Economica.

29. Kaldor N. [1978], The effect of devaluations on trade in manufactures in Further essays in Economics, Duckworth, pp.99-118.

30. Knetter M.M. [1993], International Comparisons of Pricing-to-Market Behaviour, American Economic Review, vol.83, juin, pp.473-486.

31. Krugman, P.R. [1994a], Competitiveness: a Dangerous Obsession, Foreign Affairs, vol.73, n², pp.28-44.

32. Krugman, P.R. [1994b], Proving my point, Foreign Affairs, juillet-août, vol.73, nº 4, pp.198-203.

33. Krugman, P.R. [1996], Making Sense of the Competitiveness Debate, Oxford Review of Economic Policy, vol.12, ${ }^{\circ} 3$.

34. Kumar, N. [1998], Globalization, foreign direct investment and technology transfers. Impacts on and prospects for developing countries, Routledge, $234 \mathrm{p}$.

35. Lunvall B.A. [1985], Product Innovation and User-Producer Interaction, Aalborg University Press.

36. Magnier A., Toujas-Bernate J. [1994], Technology and Trade: Empirical Evidences for the Major Five Industrialised Countries, Weltwirtschaftliches Arch, vol.130, n³, pp.494-520.

37. Markusen, J.R., A.J. Venables (1999), Foreign direct investment as a catalyst for industrial development, European Economic Review, 43, pp.335-356.

38. Mathis J., Mazier J., Rivaud-Danset D. [1988], La compétitivité industrielle, Dunod, 318p.

39. Miyashita K., Russel D.W. [1996], Keiretsu : Inside the Hidden Japanese Conglomerates, MacGrauw-Hill.

40. MucchiellI, J.L. [1998], Multinational location strategy, economics, location, management and policy, Jai Press, Greenwitch.

41. Mucchielli, J.L. [1998], Multinationales et mondialisation, Editions du Seuil, 379p.

42. Mucchielli, J.L., T. MAYER [1999], L'investissement international, Economica.

43. Nelson R.R. [1993], National innovation systems. A comparative analysis, Oxford University Press.

44. Nezeys B. [1993], La compétitivité internationale, Economica, 138p.

45. Nezeys B. [1994], Les politiques de compétitivité, Economica, 109p.

46. Niosi J., Bellon B., Saviotti P., Crow M. [1992], Les systèmes nationaux d'innovation : à la recherche d'un concept utilisable, Revue Française d'Economie, vol.7, n 1 , pp.215-250.

47. Nurbel A. [1997], L'application nuancée de la théorie des coûts de transaction aux keiretsu de production, Communication présentée au Quatrième Séminaire International de Recherche Euro-Asie, IAE Poitiers, 6 novembre, 26p.

48. Nurbel A. [2000], La question de la pertinence du concept de compétitivité de la nation : de la dangereuse obsession à la qualification de la nation en tant que facteur de compétitivité des firmes, Communication présentée au XIIème Colloque du Cedimes, Université Paris-Assas, 18-19-20 mai 2000, 23p.

49. Olofsdotter, K. [1998], Foreign direct investment, country capabilities and economic growth, Weltwirtschaftliches Arch, 134(3), pp.534-547.

50. Ozawa T. [1995], Dynamic Industrial Policy and Flexible Production: Toward a TechnostructuralEvolutionary Paradigm of MITI's Role, Revue d'Economie Industrielle, n ${ }^{\circ} 71$, pp.39-59.

51. Ozawa, T. [1992], Foreign direct investment and economic development, Transnational Corporations, vol.1, n 1 , fév., pp.27-54.

52. Papadakis M. [1994], Did (or Does) the United States Have a Competitiveness Crisis, Journal of Political Analysis and Management, vol.13, $\mathrm{n}^{\circ} 1$, pp.1-20.

53. Perroux F. [1982], Qu'est-ce qu'être compétitif, in Reiffers J.L., Economie et finance internationales, Dunod, pp.3-21.

54. Porter M.E. [1990], The Competitive Advantage of Nations, MacMillan Press Ltd, 855p.

55. Rey P., Tirole J. [1997], Analyse économique de la notion de prédation, Revue française d'Economie, vol.XII, 1, hiver, pp.3-32.

56. Rodriguez-Clare, A. (1996), Multinationals, linkages, and economic development, American Economic Review, 86(4), sept., pp.852-873.

57. Saucier P. [1991], Alliances de type Keiretsu et multinationalisation des firmes japonaises in Mucchielli J.L./Cessefi/Commissariat Général du Plan, Alliances stratégiques et firmes multinationales en Europe : rapport final, Institut d'études du commerce international, Paris. 
58. Soon, T-W, W.A. Stoever (1996), Foreign direct investment and economic development in Singapore: a policy-oriented approach, Journal of Developing Areas, 30, avril, pp.317-340.

59. Unctad [1999], World investment report 1999. Foreign direct investment and the challenge of development, United Nations, 541p.

60. Williamson O.E. [1994], Les institutions de l'économie, Interéditions, 404p.

\section{NOTES}

